\title{
Histone modifications and a choice of variant: a language that helps the genome express itself Zachary A. Gurard-Levin ${ }^{1,2,3,4,5 *}$ and Geneviève Almouzni ${ }^{1,2,3,4,5 *}$
}

Addresses: ${ }^{1}$ Institut Curie, Centre de Recherche, Paris, F-75248, France; ${ }^{2}$ CNRS, UMR3664, Paris, F-75248, France; ${ }^{3}$ Équipe Labellisée Ligue contre le Cancer, UMR3664, Paris, F-75248, France; ${ }^{4}$ UPMC, UMR3664, Paris, F-75248, France; ${ }^{5}$ Sorbonne University, PSL, Paris, France

*Corresponding authors: Zachary A. Gurard-Levin (zachary.gurard-levin@curie.fr); Geneviève Almouzni (genevieve.almouzni@curie.fr)

Fl000Prime Reports 2014, 6:76 (doi:10.12703/P6-76)

All FI000Prime Reports articles are distributed under the terms of the Creative Commons Attribution-Non Commercial License (http://creativecommons.org/licenses/by-nc/3.0/legalcode), which permits non-commercial use, distribution, and reproduction in any medium, provided the original work is properly cited.

The electronic version of this article is the complete one and can be found at: http://fl 000.com/prime/reports/b/6/76

\begin{abstract}
Covalent post-translational modifications on histones impact chromatin structure and function. Their misfunction, along with perturbations or mutations in genes that regulate their dynamic status, has been observed in several diseases. Thus, targeting histone modifications represents attractive opportunities for therapeutic intervention and biomarker discovery. The best approach to address this challenge is to paint a comprehensive picture integrating the growing number of modifications on individual residues and their combinatorial association, the corresponding modifying enzymes, and effector proteins that bind modifications. Furthermore, how they are imposed in a distinct manner during the cell cycle and on specific histone variants are important dimensions to consider. Firstly, this report highlights innovative technologies used to characterize histone modifications, and the corresponding enzymes and effector proteins. Secondly, we examine the recent progress made in understanding the dynamics and maintenance of histone modifications on distinct variants. We also discuss their roles as potential carriers of epigenetic information. Finally, we provide examples of initiatives to exploit histone modifications in cancer management, with the potential for new therapeutic opportunities.
\end{abstract}

\section{Histone marks: an evolving language}

The discovery nearly fifty years ago that gene expression correlates with hyperacetylated histones [1] hinted at the importance of factors beyond the DNA sequence and how transcription factors control genome function. In the following years, the identification of histone methylation and phosphorylation [2-4] expanded the repertoire of modifications. Then, work in yeast made the first connection between mutations in histone tails and transcription $[5,6]$, setting the stage for a functional link between histone modifications and gene expression. The connection between acetylation and chromatin function was further supported in Drosophila, using antibodies recognizing acetylated lysines on histone H4 [7]. The characterization of the first histone-modifying enzymes harboring acetyltransferase, deacetylase, methyltransferase, and demethylase activity [8-13] represented major breakthroughs, by providing a first handle on how to control the modifications. The principle of a dynamic system that responds to cellular stimuli and environmental cues to regulate chromatin structure and function emerged [14]. The presence of these modifications (or "marks") was viewed as acting in two ways: (a) directly, by altering the electrostatic potential and/or the structure of the local chromatin environment to open or restrict access to DNA or (b) indirectly, through the recruitment of effector proteins that carry out a biological event. The latter aspect led to the proposal of the histone code hypothesis that states that histone post-translational modifications (PTMs) act sequentially or in combination to signal downstream events $[15,16]$. Interestingly, the possibility that these marks could be stably propagated to contribute to the maintenance of cellular identity across many cell 
generations placed them as candidate vehicles of epigenetic information [17]. Together, these simple concepts with writers, readers, and erasers initiated a burst of interest spanning a range of scientific disciplines. Yet, we are still debating the existence of a code, defined as one or a combination of marks that signal a particular event. Furthermore, the repertoire of players continues to expand when one considers all histone modifications [18], the enzymes [19], effector proteins [20], and the different histone variants $[21,22]$, and this sophisticated language is evolving with implications in diverse biological activities $[23,24]$. In this short report, to highlight recent advances in the role of histone marks (modifications and variants), we review novel characterization techniques and provide new insight into their potential inheritance and dynamics in order to discuss emerging approaches in cancer management.

\section{An interdisciplinary effort to deconvolve a complex language}

Antibodies that recognize site-specific histone modifications remain crucial tools used to study histone marks $[7,25]$, and are routinely exploited in chromatin immunoprecipitation (ChIP) approaches. Combining ChIP with other techniques, such as with next-generation sequencing (ChIP-seq), enables the mapping of histone marks genome-wide [26-28], whereas combining it with bisulfite sequencing correlates histone marks with DNA methylation [29] and can extend to its other modified forms. One limitation is that these approaches require prior knowledge of the associated protein and/or modification, and the availability of a suitable antibody. Importantly, DNA capture techniques, combined with mass spectrometry, provide opportunities to identify unknown modifications and associated proteins. In one approach, work in yeast introduced a unique DNA sequence that is recognized by a DNA-binding protein that acts as a handle, enabling the purification of a single locus [30]. Alternatively, DNA capture using nucleotide derivatives enables the investigation of histone marks and associated proteins at sites of DNA synthesis [31,32], shedding light onto the maintenance of histone marks following replication. Finally, the recent development of gene editing tools, including transcription activator-like effector nucleases (TALENs) and clustered regularly interspaced short palindromic repeats (CRISPRs) [33-35], provides opportunities to analyze the impact of the loss of factors involved in the dynamics of histone marks.

Importantly, the binding of proteins, including antibodies, to histone marks can depend on neighboring modifications [36], potentially altering their specificity, and giving rise to artifacts. Here, chemical approaches, including advances in peptide synthesis protocols [37-40], have made significant contributions to efforts to better characterize antibody and protein binding using peptide arrays in vitro $[41,42]$. A useful systematic analysis of nearly 200 antibodies using a standardized method employed by the ENCODE consortium is available online [43] (see http:// compbio.med.harvard.edu/antibodies/). Peptide arrays have also helped in elucidating the substrate specificity for the modifying enzymes [44-47]. Remarkable advances in chemical biology include the use of label-free assays, which minimize artifacts associated with labels [48,49], and high-throughput platforms, used to identify small molecule modulators of histone modifying enzymes $[50,51]$. Finally, mass spectrometry (MS) has proven to be a powerful tool, particularly in its quantitative format $[52,53]$, used to identify novel modifications [54,55], crosstalk [56], and to explore their dynamics [57]. This use of mass spectrometry has been extensively reviewed [58-60].

Notably, many assays including ChIP provide only a snapshot of the histone modification landscape, and generally represent an average, over a population of cells. This hinders studies of dynamics, and by averaging over heterogeneous cell populations, key information can be lost or diluted. This has motivated efforts towards singlecell analyses. An early example of single-cell analysis exploited imaging techniques with the use of antibody Fab fragments coupled to fluorophores, a technique termed FabLEM [61], to visualize the dynamics of endogenous modifications in individual living cells. Another study labeled different antibodies with distinct fluorophores to simultaneously visualize multiple marks in single cells isolated using microfluidic devices [62]. Of note, these single-cell approaches tend to assess histone modifications globally across the genome. An alternative approach aims to investigate individual genomic loci in single cells [63] by combining in situ hybridization and the proximity ligation assay (PLA) [64]. This assay is compatible with histological sections [63] and could therefore extend to the clinic. Optimization of these techniques and others, such as the development of ChIPseq at single-cell levels, will open avenues for assays with applications at the bench and in the clinic.

\section{Maintenance of histone marks: should I stay or should I go?}

Histone modifications are present not only on nucleosomal histones but also on histones in transit following their synthesis. Exploiting epitope-tagged histone variants in order to purify soluble histone complexes [65] revealed that different pools of non-nucleosomal 
histones feature distinct marks [66,67], and some are more prevalent on particular variants [68]. Thus, the issue of the histone variants, whose expression is cell cycle regulated, is a critical component of the picture $[21,22]$.

When present in chromatin, histone modifications are commonly referred to as epigenetic marks, yet often function simply as a signaling module in the short-term and their longevity is still under exploration. To be formally considered an epigenetic mark (as defined by Robin Holliday), the modification should be stably inherited through cell division in the absence of the initiating event [69]. However, dynamics through the cell cycle, in particular during replication (where there is a genome-wide transient disruption of the chromatin organization), challenges heritability. In the wake of the replication fork passage, parental histones are interspersed with newly synthesized histones, diluting parental marks (Figure 1) [70,71]. Notably, evicted parental H3-H4 tetramers are thought to remain intact and to randomly distribute to daughter cells in cultured cells. However, some tetramers could proceed through a dimeric state, and then either rapidly re-associate or remain dimeric and mix with new H3-H4 dimers. Several factors are implicated in these processes to ensure proper packaging of the duplicated DNA [72,73], in particular histone chaperones [74], which represent key players in epigenetic inheritance. Indeed, the histone chaperone anti-silencing function 1 (ASF1) is a candidate to coordinate the recycling of parental and new histones (and associated modifications). Through its connection with the MCM2 helicase [75], ASF1 handles parental $\mathrm{H} 3-\mathrm{H} 4$ dimers and can associate with new H3-H4 dimers, acting as a donor to hand off histones to another H3-H4 chaperone, chromatin assembly factor 1 (CAF-1). CAF-1 acts in a manner coupled to DNA synthesis to deposit the replicative H3.1 variant [65]. Failure in the deposition process can present gaps that are later filled by the histone regulator A (HIRA) chaperone to deposit H3.3 throughout the cell cycle [76]. Importantly, these dynamics may differ in various cellular contexts or cell types. In any event, it is interesting to consider the impact of recycling parental histones and associated marks where nucleosomes feature asymmetric modifications [77] and/or histone variant heterotypic particles [78].

Once deposited, the landscape of histone modifications and variants may be altered through replication-independent dynamics $[76,79]$ and may have an impact on chromatin function. Indeed, H3.3 accumulates at transcription sites and regulatory elements [76] deposited by either the HIRA or DAXX (death associated protein) chaperones. Furthermore, a recent example in yeast shows that the Set2-mediated methylation of H3K36 impacts replication-independent dynamics that can alter the acetylation state and give rise to cryptic transcription. Perturbation of this methylation pathway, perhaps by altering the expression or activity of the Set 2 methyltransferase or an H3K36 demethylase (KDM4A), promotes nucleosome turnover and results in an accumulation of acetylated histones at the coding regions of genes, allowing transcription factors access to cryptic sites [80]. Histone marks may also be maintained following replication due to histone-modifying enzymes (Figure 2A), some possibly associated with the replication fork [81]. Interestingly, the placement of variants can potentiate the action of enzymes, such as SUV39h1 (suppressor of variegation 3-9 homo$\log 1$ ), an H3K9 methyltransferase [12]. Indeed, H3K9me1, more prevalent on soluble H3.1 compared to H3.3 [68], is a preferred substrate for SUV39h1 to establish H3K9me3. This leads to the binding of the heterochromatin protein 1 (HP1), a mark of pericentric heterochromatin [82]. Furthermore, existing modifications may recruit enzyme complexes to write modifications on neighboring newly synthesized histones. For example, the polycomb group (PcG) protein complex can recognize and bind to H3K27me3-modified histones. This suggests a model where the PcG complex can bind parental H3K27me3 histones, thereby recruiting enzymatic activity to newly synthesized histones to spread this mark (Figure 2B) [83]. Indeed, in Drosophila, a mutation in the PCG protein EED, which impairs its ability to bind H3K27me3, decreases global H3K27me3 levels [83]. While MS approaches support a model where H3K27me3 remains following replication $[31,84,85]$, a study in Drosophila embryos (using the PLA assay) failed to detect H3K27me3 at replication foci but rather observed the responsible enzyme, enhancer of zeste (E[z]) [86]. It will be interesting to further test this effect with other assays and in different model organisms. Interestingly, recent work in plants shows that histone variants can also impact H3K27 methylation. Here, the enzymes ATXR (arabidopsis trithorax-related protein) 5 and ATXR6 specifically monomethylate $\mathrm{H} 3.1 \mathrm{~K} 27$, as plant H3.3-specific T31 inhibits methylation, an effect not observed with other plant methyltransferases (Figure 2C) [87]. Together, these examples highlight the importance of assay choice and model systems when analyzing histone modifications and suggest that even conserved modifications may be subject to different regulatory mechanisms in various species. Notably, it is important to consider instances where histones do not have the capacity to bear the same modifications either due to mutations [88-91] or the presence of variants, such as the centromeric $\mathrm{H} 3$ variant 
Figure I. The choreography of histone modifications and variants at the replication fork with their chaperones
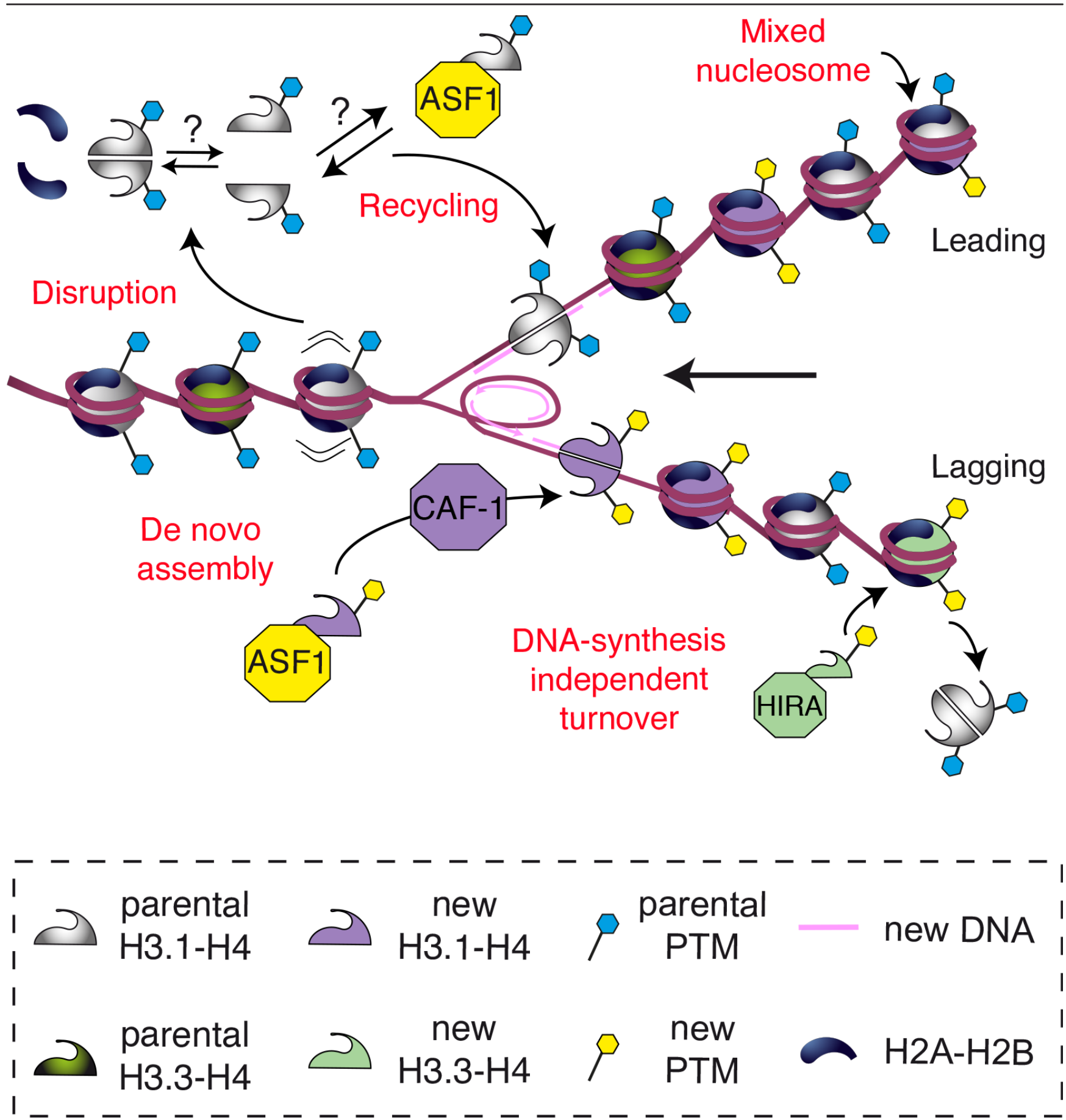

Histone chaperones participate in histone deposition during replication and are key candidates to regulate epigenetic inheritance. Parental $\mathrm{H} 3-\mathrm{H} 4 \mathrm{histones}$ evicted from chromatin are handled by the chaperone ASFI, which also associates with newly synthesized histones [75]. Parental histones and marks are recycled onto daughter strands along with newly synthesized histones with characteristic marks [68, 107], the latter deposited by the chaperone CAF-I. Mixing of parental and new histones is rare [108] but may have functional consequences. Importantly, away from the fork, histones are susceptible to turnover, which can alter the modification landscape.

Abbreviations: ASFI, anti-silencing function I; CAF-I, chromatin assembly factor I; HIRA, histone regulator A; PTM, post-translational modification. 
Figure 2. Histone modification dynamics and maintenance mechanisms

\section{A Opposing enzyme activities maintain steady-state levels}

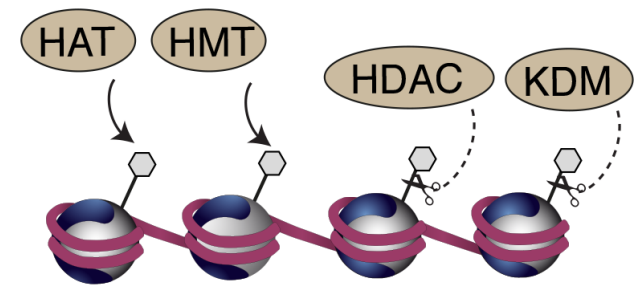

B
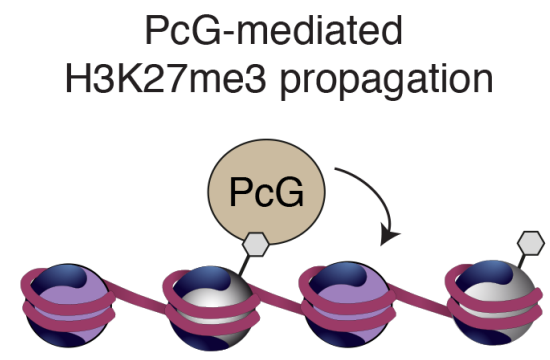

C Variant-specific residues may influence enzyme activity
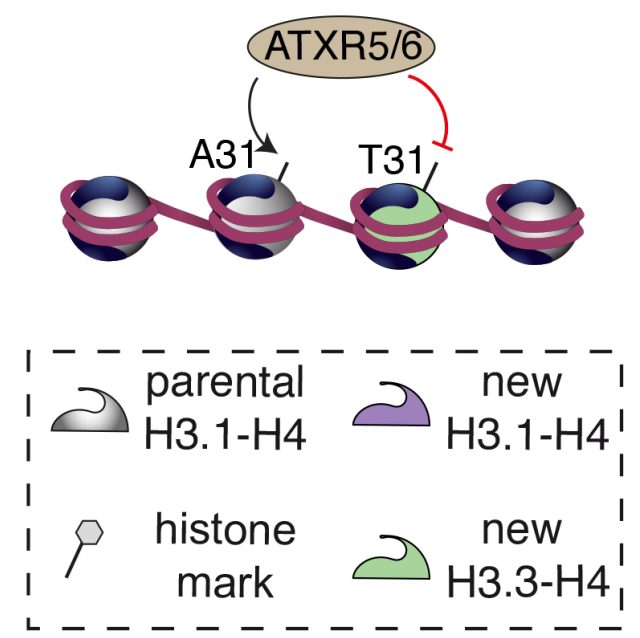

(A) Enzymes having opposing activities maintain steady-state levels of histone marks. (B) A model where the polycomb group protein complex propagates H3K27me3 by binding to the parental histone mark, which recruits the responsible enzyme to methylate neighboring nucleosomes [83]. (C) Histone variant-specific residues can influence how enzymes entertain their substrates, as shown with the ATXR5/6 methyltransferases in plants, where T3I (S3I in mammals) inhibits monomethylation of $\mathrm{H} 3 \mathrm{~K} 27$ [87].

Abbreviations: ATXR, arabidopsis trithorax-related protein; HAT, histone acetyltransferase; HDAC, histone deacetylase; HMT, histone methyltransferase; (note $\mathrm{H}$ is sometimes replaced with $\mathrm{K}$ to represent lysine methyltransferase - see [109]); KDM, lysine demethylase; PcG, polycomb group protein.
CenH3 (also known as CENP-A) [92], which lack the target residue and how this can impact chromatin integrity.

\section{Code red! Histone marks in cancer}

Genomic and epigenomic factors are now recognized as contributing to cancer [93-96]. Interestingly, recent evidence showcases links between the genome and epigenome, leading to new questions about how they cooperate in order to impact cancer progression and whether this can be exploited to better manage patient care. A pioneering study identified mutations in histone H3, including H3K27M, in pediatric glioblastoma [88], a finding recently supported in several new reports [89-91,97]. Biochemical evidence shows that even a fraction of histones presenting this mutation is sufficient to impact global H3K27 methylation levels [98]. Additionally, new data have shed light on how histone marks impact genome stability. The overexpression of KDM4A, which demethylates H3K9 and H3K36, leads to site-specific copy gain of regions often amplified in human tumors [99]. Interestingly, SUV39h1 or HP1 $\gamma$ (which binds H3K9me3) antagonizes this effect, highlighting the importance of balancing opposing enzyme activities [99]. Furthermore, a selective inhibitor for an H3K79 methyltransferase kills acute leukemia lines bearing mixed lineage leukaemia (MLL) translocations [100], bringing hope of a therapy for this disease that has limited treatment options. It will be important to better understand the links between genome and epigenome as this may identify novel candidates for targeted therapeutic intervention, particularly in cancers with distinct genome anomalies.

The histone-modifying enzymes are common targets for identifying small molecule modulators. However, highly conserved active sites among similar enzymes have challenged the development of selective inhibitors. Interestingly, the sensitivity to histone deacetylase (HDAC) inhibitors varies depending on the protein complex [101], suggesting that altering the concentration of the inhibitor may target different HDAC complexes and thereby different groups of genes. An emerging strategy is to target the effector proteins, such as the bromoand chromodomains, which bind acetylated and methylated lysines, respectively. Indeed, the demonstration that small molecule bromodomain inhibitors, such as JQ1 [102] and i-BET [103], can alter gene expression has motivated additional screens for other inhibitors. The Structural Genomics Consortium (SGC) has identified several potential epidrugs and has made them and corresponding structural information available to the research community (for more information see www. thesgc.org), advancing our understanding of how epidrugs impact cell function. Another approach that has gained momentum is combining "epidrugs", either with other "epidrugs" or with classical therapeutic 
regimes. Indeed, combining certain demethylase inhibitors with pan-HDAC inhibitors has a synergistic effect on cell death in glioblastoma cells, providing a proof-ofconcept to test other combinations of epidrugs for enhanced sensitivity [104]. Interestingly, changing the chromatin structure through epidrugs also sensitizes cells to radiation [105]. This could enable lower doses and higher selectivity to cancer cells and minimize harmful side effects. Epidrugs have also shown promise in slowing the onset of resistance or reversing the resistant phenotype [106]. The future success of epidrugs in the clinic will depend on a better understanding of how these compounds function in cells, thus necessitating studies integrating several aspects of chromatin dynamics. Furthermore, identifying markers that could be exploited as companion diagnostics will help identify the patients that will most likely clinically benefit, improving overall patient care.

\section{Conclusions and perspectives}

The past few years have seen significant progress in our understanding of histone marks and their implications in diverse biological processes. However, several important questions remain. How can mutations in histones found in certain cancers alter the histone modification landscape and thus chromatin function? How do enzymes of opposing activities cooperate to establish a modification landscape with proper dynamics? Are histone modifications propagated through cell division and if yes is this inheritance due to the presence of recycled parental marks or a cellular memory that acts to re-establish the marks? Are variations in the dynamics of the chromatin landscape a cause or consequence of tumorigenesis? What is the impact of epidrugs on the global histone modification landscape, genome integrity, and on the proteome, featuring thousands of modification substrates? The answers to these questions should help place histone modifications within the network of other chromatin regulators and strengthen the link with both development and disease. In this respect, the histone variants deserve consideration in the histone code debate as the variants themselves impact the modification landscape as well as the dynamics of the genome itself, exemplified during DNA damage [79]. Code or not, the continuous development of new assays, including single-cell approaches, should help provide further insight into several aspects of histone modifications, such as cause or consequence of particular marks, and help identify novel biomarkers and targeted candidates for therapeutic intervention.

\section{Abbreviations}

ASF1, anti-silencing function 1; CAF-1, chromatin assembly factor 1; ChIP, chromatin immunoprecipitation;
ChIP-seq, chromatin immunoprecipitation with next generation sequencing; HDAC, histone deacetylase; HIRA, histone regulator $\mathrm{A}$; $\mathrm{HP1}$, heterochromatin protein 1 ; MS, mass spectrometry; PcG, polycomb group protein; PLA, proximity ligation assay; PTM, post-translational modification; SGC, Structural Genomics Consortium; SUV39h1, suppressor of variegation 3-9 homolog 1.

\section{Disclosures}

The authors declare that they have no disclosures.

\section{Acknowledgments}

We thank Angela Taddei and Dan Filipescu for critical reading. The Almouzni lab is supported by la Ligue Nationale contre le Cancer (Equipe labellisée Ligue and postdoctoral fellowship to Zachary A. Gurard-Levin), the European Commission Network of Excellence EpiGeneSys (HEALTH-F4-2010-257082), ERC Advanced Grant 2009AdG_20090506 "Eccentric", the European Commission large-scale integrating project FP7_HEALTH-2010-259743 "MODHEP", ANR "ChromaTin" ANR-10-BLAN-1326-03, ANR-11-LABX-0044_DEEP and ANR-10-IDEX-0001-02 PSL*, ANR "CHAPINHIB" ANR-12-BSV5-0022-02 and Aviesan-ITMO cancer project "Epigenomics of breast cancer".

\section{References}

I. Allfrey VG, Mirsky AE: Structural Modifications of Histones and their Possible Role in the Regulation of RNA Synthesis. Science 1964, | 44:559.

2. Allfrey VG, Faulkner R, Mirsky AE: Acetylation and methylation of histones and their possible role in the regulation of RNA synthesis. Proc Natl Acad Sci USA 1964, 5 I:786-94.

3. Murray K: The occurence of epsilon-N-methyl lysine in histones. Biochemistry 1964, 3:10-5.

4. Stevely WS, Stocken LA: Phosphorylation of rat-thymus histone. Biochem J 1966, I00:20C-IC.

5. Han M, Kim UJ, Kayne P, Grunstein M: Depletion of histone H4 and nucleosomes activates the PHO5 gene in Saccharomyces cerevisiae. EMBO J 1988, 7:2221-8.

6. Johnson LM, Kayne PS, Kahn ES, Grunstein M: Genetic evidence for an interaction between SIR3 and histone $\mathrm{H} 4$ in the repression of the silent mating loci in Saccharomyces cerevisiae. Proc Nat Acad Sci USA 1990, 87:6286-90.

7. Turner BM, Birley AJ, Lavender J: Histone $\mathbf{H 4}$ isoforms acetylated at specific lysine residues define individual chromosomes and chromatin domains in Drosophila polytene nuclei. Cell I992, 69:375-84

8. Travis GH, Colavito-Shepanski M, Grunstein M: Extensive purification and characterization of chromatin-bound histone acet-yltransferase from Saccharomyces cerevisiae. J Biol Chem 1984, 259:|4406-I2.

9. Kleff S, Andrulis ED, Anderson CW, Sternglanz R: Identification of a gene encoding a yeast histone $\mathrm{H} 4$ acetyltransferase. J Biol Chem 1995, 270:24674-7.

10. Brownell JE, Zhou J, Ranalli T, Kobayashi R, Edmondson DG, Roth SY, Allis CD: Tetrahymena histone acetyltransferase A: 
a homolog to yeast $\mathbf{G c n} 5 p$ linking histone acetylation to gene activation. Cell 1996, 84:843-5I.

\section{FIOOOPrime}

II. Taunton J, Hassig CA, Schreiber SL: A mammalian histone deacetylase related to the yeast transcriptional regulator Rpd3p. Science 1996, 272:408-II.

12. Rea S, Eisenhaber F, O'Carroll D, Strahl BD, Sun ZW, Schmid M, Opravil S, Mechtler K, Ponting CP, Allis CD, Jenuwein T: Regulation of chromatin structure by site-specific histone $\mathrm{H} 3$ methyltransferases. Nature 2000, 406:593-9.

\section{FIOOOPrime}

13. Shi Y, Lan F, Matson C, Mulligan P, Whetstine JR, Cole PA, Casero RA, Shi Y: Histone demethylation mediated by the nuclear amine oxidase homolog LSDI. Cell 2004, I I 9:94I-53.

\section{FlOOOPrime \\ RECOMMENDED}

14. Turner BM: Acetylation and deacetylation of histone H4 continue through metaphase with depletion of more-acetylated isoforms and altered site usage. Exp Cell Res 1989, I82:206-14.

15. Strahl BD, Allis CD: The language of covalent histone modifications. Nature 2000, 403:4I-5.

16. Jenuwein T, Allis CD: Translating the histone code. Science 200 I, 293: $1074-80$

\section{FlOOOPrime
RECOMMENDED}

17. Turner BM: Histone acetylation and an epigenetic code. Bioessays 2000, 22:836-45.

18. Dhall A, Chatterjee C: Chemical approaches to understand the language of histone modifications. ACS Chem Biol 201I, 6:987-99.

19. Bojang P, Ramos KS: The promise and failures of epigenetic therapies for cancer treatment. Cancer Treat Rev 2014, 40:153-69.

20. Taverna SD, Li H, Ruthenburg AJ, Allis CD, Patel DJ: How chromatin-binding modules interpret histone modifications: lessons from professional pocket pickers. Nat Struct Mol Biol 2007, I4:1025-40.

21. Szenker E, Ray-Gallet D, Almouzni G: The double face of the histone variant H3.3. Cell Res 20II, 2I:42I-34.

22. Filipescu D, Szenker E, Almouzni G: Developmental roles of histone $\mathbf{H 3}$ variants and their chaperones. Trends Genet 2013, 29:630-40.

23. Bannister AJ, Kouzarides T: Regulation of chromatin by histone modifications. Cell Res 201 I, 21:38I-95.

24. Rivera C, Gurard-Levin ZA, Almouzni G, Loyola A: Histone lysine methylation and chromatin replication. Biochim Biophys Acta 2014.

25. Fuchs SM, Strahl BD: Antibody recognition of histone posttranslational modifications: emerging issues and future prospects. Epigenomics 20I I, 3:247-9.

26. Barski A, Cuddapah S, Cui K, Roh T, Schones DE, Wang Z, Wei G, Chepelev I, Zhao K: High-resolution profiling of histone methylations in the human genome. Cell 2007, I29:823-37.

\section{FlOOOPrime \\ RECOMMENDED}

27. Mikkelsen TS, Ku M, Jaffe DB, Issac B, Lieberman E, Giannoukos G, Alvarez P, Brockman W, Kim T, Koche RP, Lee W, Mendenhall E, O'Donovan A, Presser A, Russ C, Xie X, Meissner A, Wernig M, Jaenisch R, Nusbaum C, Lander ES, Bernstein BE: Genome-wide maps of chromatin state in pluripotent and lineage-committed cells. Nature 2007, 448:553-60.
28. Johnson DS, Mortazavi A, Myers RM, Wold B: Genome-wide mapping of in vivo protein-DNA interactions. Science 2007, 316:1497-502.

\section{FlOOOPrime}

\section{RECOMMENDED}

29. Brinkman $A B$, Gu H, Bartels, Stefanie J J, Zhang $Y$, Matarese $F$, Simmer F, Marks H, Bock C, Gnirke A, Meissner A, Stunnenberg HG: Sequential ChIP-bisulfite sequencing enables direct genomescale investigation of chromatin and DNA methylation crosstalk. Genome Res 2012, 22:। I28-38.

\section{FlOOOPrime \\ RECOMMENDED}

30. Byrum SD, Raman A, Taverna SD, Tackett AJ: ChAP-MS: a method for identification of proteins and histone posttranslational modifications at a single genomic locus. Cell $\operatorname{Rep} 2012$, 2:198-205.

\section{FlOOOPrime}

RECOMMENDED

31. Alabert C, Bukowski-Wills J, Lee S, Kustatscher G, Nakamura K, de Lima Alves, Flavia, Menard P, Mejlvang J, Rappsilber J, Groth A: Nascent chromatin capture proteomics determines chromatin dynamics during DNA replication and identifies unknown fork components. Nat Cell Biol 2014, 16:28I-93.

\section{FIOOOPrime} RECOMMENDED

32. Sirbu BM, McDonald WH, Dungrawala $H$, Badu-Nkansah A, Kavanaugh GM, Chen Y, Tabb DL, Cortez D: Identification of proteins at active, stalled, and collapsed replication forks using isolation of proteins on nascent DNA (iPOND) coupled with mass spectrometry. J Biol Chem 2013, 288:31458-67.

\section{FlOOOPrime}

\section{RECOMMENDED}

33. Maeder ML, Angstman JF, Richardson ME, Linder SJ, Cascio VM, Tsai SQ, Ho QH, Sander JD, Reyon D, Bernstein BE, Costello JF, Wilkinson MF, Joung JK: Targeted DNA demethylation and activation of endogenous genes using programmable TALETET I fusion proteins. Nat Biotechnol 20 I3, 3 I: | | 37-42.

\section{FlOOOPrime \\ RECOMMENDED}

34. Mendenhall EM, Williamson KE, Reyon D, Zou JY, Ram O, Joung JK, Bernstein BE: Locus-specific editing of histone modifications at endogenous enhancers. Nat Biotechnol 2013, 3 I: I I33-6.

\section{FIOOOPrime
RECOMMENDED}

35. Konermann S, Brigham MD, Trevino AE, Hsu PD, Heidenreich M, Le Cong, Platt RJ, Scott DA, Church GM, Zhang F: Optical control of mammalian endogenous transcription and epigenetic states. Nature 2013, 500:472-6.

\section{FlOOOPrime \\ RECOMMENDED}

36. Fuchs SM, Krajewski K, Baker RW, Miller VL, Strahl BD: Influence of combinatorial histone modifications on antibody and effector protein recognition. Curr Biol 201 I, 2I:53-8.

\section{FlOOOPrime}

37. Simon MD, Chu F, Racki LR, de la Cruz, Cecile C, Burlingame AL, Panning B, Narlikar GJ, Shokat KM: The site-specific installation of methyl-lysine analogs into recombinant histones. Cell 2007, 128: $1003-12$.

\section{FlOOOPrime} RECOMMENDED

38. Neumann H, Hancock SM, Buning R, Routh A, Chapman L, Somers J, Owen-Hughes T, van Noort J, Rhodes D, Chin JW: A method for genetically installing site-specific acetylation in recombinant 
histones defines the effects of H3 K56 acetylation. Mol Cell 2009, 36:153-63.

FIOOOPRime
RECOMMENDED

39. Kee J, Villani B, Carpenter LR, Muir TW: Development of stable phosphohistidine analogues. J Am Chem Soc 2010, 132:14327-9.

\section{FlOOOPrime
RECOMMENDED}

40. Chatterjee C, McGinty RK, Fierz B, Muir TW: Disulfide-directed histone ubiquitylation reveals plasticity in $\mathrm{hDot} I \mathrm{~L}$ activation. Nat Chem Biol 2010, 6:267-9.

4I. Rothbart SB, Krajewski K, Strahl BD, Fuchs SM: Peptide microarrays to interrogate the "histone code". Meth Enzymol 2012, 5। 2: 107-35.

\section{FlOOOPrime}

\section{RECOMMENDED}

42. Bock I, Dhayalan A, Kudithipudi S, Brandt O, Rathert P, Jeltsch A: Detailed specificity analysis of antibodies binding to modified histone tails with peptide arrays. Epigenetics 20II, 6:256-63.

\section{FlOOOPrime} RECOMMENDED

43. Egelhofer TA, Minoda A, Klugman S, Lee K, Kolasinska-Zwierz P, Alekseyenko AA, Cheung M, Day DS, Gadel S, Gorchakov AA, Gu T, Kharchenko PV, Kuan S, Latorre I, Linder-Basso D, Luu Y, Ngo Q, Perry M, Rechtsteiner A, Riddle NC, Schwartz YB, Shanower GA, Vielle A, Ahringer J, Elgin, Sarah C R, Kuroda MI, Pirrotta V, Ren B, Strome S, Park PJ, et al.: An assessment of histone-modification antibody quality. Nat Struct Mol Biol 201 I, 18:91-3.

\section{FIOOOPrime}

44. Gurard-Levin ZA, Kilian KA, Kim J, Bähr K, Mrksich M: Peptide arrays identify isoform-selective substrates for profiling endogenous lysine deacetylase activity. ACS Chem Biol 2010, 5:863-73.

45. Ibáñez G, McBean JL, Astudillo YM, Luo M: An enzyme-coupled ultrasensitive luminescence assay for protein methyltransferases. Anal Biochem 2010, 40I:203-10.

\section{FlOOOPrime}

46. Garske AL, Craciun G, Denu JM: A combinatorial H4 tail library for exploring the histone code. Biochemistry 2008, 47:8094-102.

\section{FlOOOPrime \\ RECOMMENDED}

47. Moyle PM, Muir TW: Method for the synthesis of mono-ADPribose conjugated peptides. J Am Chem Soc 2010, I32:15878-80.

\section{FlOOOPrime}

\section{RECOMMENDED}

48. Gurard-Levin ZA, Mrksich M: The activity of HDAC8 depends on local and distal sequences of its peptide substrates. Biochemistry 2008, 47:6242-50.

49. Kaeberlein M, McDonagh T, Heltweg B, Hixon J, Westman EA, Caldwell SD, Napper A, Curtis R, DiStefano PS, Fields S, Bedalov A, Kennedy BK: Substrate-specific activation of sirtuins by resveratrol. J Biol Chem 2005, 280: I7038-45.

\section{FlOOOPrime}

\section{RECOMMENDED}

50. Gurard-Levin ZA, Scholle MD, Eisenberg AH, Mrksich M: Highthroughput screening of small molecule libraries using SAMDI mass spectrometry. ACS Comb Sci 20II, 13:347-50.

51. Plant M, Dineen T, Cheng A, Long AM, Chen H, Morgenstern KA: Screening for lysine-specific demethylase-I inhibitors using a label-free high-throughput mass spectrometry assay. Anal Biochem 20II, 419:217-27.

\section{FlOOOPrime} RECOMMENDED
52. Ong S, Blagoev B, Kratchmarova I, Kristensen DB, Steen H, Pandey A Mann M: Stable isotope labeling by amino acids in cell culture, SILAC, as a simple and accurate approach to expression proteomics. Mol Cell Proteomics 2002, I:376-86.

53. Su X, Ren C, Freitas MA: Mass spectrometry-based strategies for characterization of histones and their post-translational modifications. Expert Rev Proteomics 2007, 4:2 II-25.

54. Tessarz P, Santos-Rosa H, Robson SC, Sylvestersen KB, Nelson CJ, Nielsen ML, Kouzarides $T$ : Glutamine methylation in histone H2A is an RNA-polymerase-I-dedicated modification. Nature 2014, 505:564-8.

FIOOOPRime

55. Tan M, Luo H, Lee S, Jin F, Yang JS, Montellier E, Buchou T, Cheng Z, Rousseaux S, Rajagopal N, Lu Z, Ye Z, Zhu Q, Wysocka J, Ye Y, Khochbin S, Ren B, Zhao Y: Identification of $\mathbf{6 7}$ histone marks and histone lysine crotonylation as a new type of histone modification. Cell 20II, I46:1016-28.

\section{FlOOOPrime
RECOMMENDED}

56. Ruthenburg AJ, Li H, Milne TA, Dewell S, McGinty RK, Yuen M, Ueberheide B, Dou Y, Muir TW, Patel DJ, Allis CD: Recognition of a mononucleosomal histone modification pattern by BPTF via multivalent interactions. Cell 20II, 145:692-706.

\section{FlOOOPrime}

RECOMMENDED

57. Xu C, Cole PA, Meyers DJ, Kormish J, Dent S, Zaret KS: Chromatin "prepattern" and histone modifiers in a fate choice for liver and pancreas. Science 2011, 332:963-6.

\section{FIOOOPrime} RECOMMENDED

58. Zee BM, Young NL, Garcia BA: Quantitative proteomic approaches to studying histone modifications. Curr Chem Genomics 2011, 5:106-14.

59. Garcia BA: Mass spectrometric analysis of histone variants and post-translational modifications. Front Biosci (Schol Ed) 2009, I: $142-53$.

60. Eberl HC, Mann M, Vermeulen M: Quantitative proteomics for epigenetics. Chembiochem 20II, I2:224-34.

61. Hayashi-Takanaka Y, Yamagata K, Wakayama T, Stasevich TJ, Kainuma T, Tsurimoto T, Tachibana M, Shinkai $Y$, Kurumizaka H, Nozaki N, Kimura H: Tracking epigenetic histone modifications in single cells using Fab-based live endogenous modification labeling. Nucleic Acids Res 20I I, 39:6475-88.

\section{FlOOOPrime}

62. Murphy PJ, Cipriany BR, Wallin CB, Ju CY, Szeto K, Hagarman JA, Benitez JJ, Craighead HG, Soloway PD: Single-molecule analysis of combinatorial epigenomic states in normal and tumor cells. Proc Natl Acad Sci USA 2013, I 1 0:7772-7.

\section{FlOOOPrime \\ RECOMMENDED}

63. Gomez D, Shankman LS, Nguyen AT, Owens GK: Detection of histone modifications at specific gene loci in single cells in histological sections. Nat Methods 2013, 10:171-7.

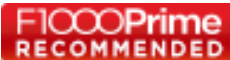

64. Weibrecht I, Leuchowius K, Clausson C, Conze T, Jarvius M, Howell WM, Kamali-Moghaddam M, Söderberg O: Proximity ligation assays: a recent addition to the proteomics toolbox. Expert Rev Proteomics 2010, 7:401-9.

65. Tagami H, Ray-Gallet D, Almouzni G, Nakatani Y: Histone H3. I and H3.3 complexes mediate nucleosome assembly pathways 
dependent or independent of DNA synthesis. Cell 2004, I| $6: 5|-6|$.

\section{FlOOOPrime}

66. Campos El, Fillingham J, Li G, Zheng H, Voigt P, Kuo WW, Seepany H, Gao Z, Day LA, Greenblatt JF, Reinberg D: The program for processing newly synthesized histones $\mathrm{H} 3 . \mathrm{I}$ and H4. Nat Struct Mol Biol 2010, 17:|343-5I.

\section{FlOOOPrime} RECOMMENDED

67. Alvarez F, Muñoz F, Schilcher P, Imhof A, Almouzni G, Loyola A: Sequential establishment of marks on soluble histones $H 3$ and H4. J Biol Chem 20II, 286: I77I 4-2I.

68. Loyola A, Bonaldi T, Roche D, Imhof A, Almouzni G: PTMs on H3 variants before chromatin assembly potentiate their final epigenetic state. Mol Cell 2006, 24:309-16.

\section{FlOOOPrime RECOMMENDED}

69. Holliday R: DNA methylation and epigenetic inheritance. Philos Trans R Soc Lond B, Biol Sci 1990, 326:329-38.

70. Jasencakova Z, Scharf, Annette N D, Ask K, Corpet A, Imhof A, Almouzni G, Groth A: Replication stress interferes with histone recycling and predeposition marking of new histones. Mol Cell 2010, 37:736-43.

7I. Jansen, Lars E T, Black BE, Foltz DR, Cleveland DW: Propagation of centromeric chromatin requires exit from mitosis. J Cell Biol 2007, 176:795-805.

\section{FlOOOPrime}

\section{RECOMMENDED}

72. Corpet A, Almouzni G: Making copies of chromatin: the challenge of nucleosomal organization and epigenetic information. Trends Cell Biol 2009, 19:29-41.

73. Alabert $C$, Groth $A$ : Chromatin replication and epigenome maintenance. Nat Rev Mol Cell Biol 2012, 13:153-67.

74. Gurard-Levin ZA, Quivy J, Almouzni G: Histone chaperones: assisting histone traffic and nucleosome dynamics. Annu Rev Biochem 20I4, 83:487-5I7.

75. Groth A, Corpet A, Cook, Adam J L, Roche D, Bartek J, Lukas J, Almouzni G: Regulation of replication fork progression through histone supply and demand. Science 2007, 3 I 8: | 928-3। .

\section{FlOOOPrime \\ RECOMMENDED}

76. Ray-Gallet D, Woolfe A, Vassias I, Pellentz C, Lacoste N, Puri A, Schultz DC, Pchelintsev NA, Adams PD, Jansen, Lars E T, Almouzni G: Dynamics of histone $\mathrm{H} 3$ deposition in vivo reveal a nucleosome gap-filling mechanism for $\mathrm{H} 3.3$ to maintain chromatin integrity. Mol Cell 20II, 44:928-41.

77. Voigt P, LeRoy G, Drury WJ, Zee BM, Son J, Beck DB, Young NL, Garcia BA, Reinberg D: Asymmetrically modified nucleosomes. Cell 20I2, I5I:I8I-93.

\section{FlOOOPRime}

78. Lacoste N, Woolfe A, Tachiwana H, Garea AV, Barth T, Cantaloube S, Kurumizaka H, Imhof A, Almouzni G: Mislocalization of the centromeric histone variant CenH3/CENP-A in human cells depends on the chaperone DAXX. Mol Cell 2014, 53:631-44.

79. Adam S, Polo SE, Almouzni G: Transcription recovery after DNA damage requires chromatin priming by the $\mathrm{H} 3.3$ histone chaperone HIRA. Cell 20I3, 155:94-106.

80. Venkatesh S, Smolle M, Li H, Gogol MM, Saint M, Kumar S, Natarajan K, Workman JL: Set2 methylation of histone $H_{3}$ lysine $\mathbf{3 6}$ suppresses histone exchange on transcribed genes. Nature 2012, 489:452-5.
8I. Petruk S, Black KL, Kovermann SK, Brock HW, Mazo A: Stepwise histone modifications are mediated by multiple enzymes that rapidly associate with nascent DNA during replication. Nat Commun 20I3, 4:284I.

82. Maison C, Almouzni G: HPI and the dynamics of heterochromatin maintenance. Nat Rev Mol Cell Biol 2004, 5:296-304.

83. Margueron R, Justin N, Ohno K, Sharpe ML, Son J, Drury WJ, Voigt P, Martin SR, Taylor WR, Marco V de, Pirrotta V, Reinberg D, Gamblin SJ: Role of the polycomb protein EED in the propagation of repressive histone marks. Nature 2009, 461:762-7.

\section{FIOOOPrime}

RECOMMENDED

84. Zee BM, Levin RS, Dimaggio PA, Garcia BA: Global turnover of histone post-translational modifications and variants in human cells. Epigenetics Chromatin 2010, 3:22.

85. Barth TK, Imhof A: Fast signals and slow marks: the dynamics of histone modifications. Trends Biochem Sci 20I0, 35:618-26.

86. Petruk S, Sedkov Y, Johnston DM, Hodgson JW, Black KL, Kovermann SK, Beck S, Canaani E, Brock HW, Mazo A: TrxG and PcG proteins but not methylated histones remain associated with DNA through replication. Cell 2012, 150:922-33.

\section{FlOOOPrime
RECOMMENDED}

87. Jacob Y, Bergamin E, Donoghue, Mark T A, Mongeon V, LeBlanc C, Voigt P, Underwood CJ, Brunzelle JS, Michaels SD, Reinberg D, Couture J, Martienssen RA: Selective methylation of histone H3 variant $\mathbf{H} 3.1$ regulates heterochromatin replication. Science 2014, 343:1249-53.

\section{FlOOOPrime}

\section{RECOMMENDED}

88. Schwartzentruber J, Korshunov A, Liu X, Jones, David T W, Pfaff E, Jacob K, Sturm D, Fontebasso AM, Quang DK, Tönjes M, Hovestadt V, Albrecht S, Kool M, Nantel A, Konermann C, Lindroth A, Jäger N, Rausch T, Ryzhova M, Korbel JO, Hielscher T, Hauser P, Garami M, Klekner A, Bognar L, Ebinger M, Schuhmann MU, Scheurlen W, Pekrun A, Frühwald MC, et al:: Driver mutations in histone H3.3 and chromatin remodelling genes in paediatric glioblastoma. Nature 2012, 482:226-31.

\section{FlOOOPrime}

\section{RECOMMENDED}

89. Fontebasso AM, Papillon-Cavanagh S, Schwartzentruber J, Nikbakht $\mathrm{H}$, Gerges N, Fiset P, Bechet D, Faury D, Jay N de, Ramkissoon LA, Corcoran A, Jones, David T W, Sturm D, Johann P, Tomita T, Goldman S, Nagib M, Bendel A, Goumnerova L, Bowers DC, Leonard JR, Rubin JB, Alden T, Browd S, Geyer JR, Leary S, Jallo G, Cohen K, Gupta N, Prados MD, et al:: Recurrent somatic mutations in ACVRI in pediatric midline high-grade astrocytoma. Nat Genet 2014, 46:462-6.

90. Taylor KR, Mackay A, Truffaux N, Butterfield YS, Morozova O, Philippe C, Castel D, Grasso CS, Vinci M, Carvalho D, Carcaboso AM, Torres C de, Cruz O, Mora J, Entz-Werle N, Ingram WJ, Monje M, Hargrave D, Bullock AN, Puget S, Yip S, Jones C, Grill J: Recurrent activating ACVRI mutations in diffuse intrinsic pontine glioma. Nat Genet 2014, 46:457-6I.

91. Buczkowicz P, Hoeman C, Rakopoulos P, Pajovic S, Letourneau L, Dzamba M, Morrison A, Lewis P, Bouffet E, Bartels U, Zuccaro J, Agnihotri S, Ryall S, Barszczyk M, Chornenkyy Y, Bourgey M, Bourque G, Montpetit A, Cordero F, Castelo-Branco P, Mangerel J, Tabori U, Ho KC, Huang A, Taylor KR, Mackay A, Bendel AE, Nazarian J, Fangusaro JR, Karajannis MA, et al.: Genomic analysis of diffuse intrinsic pontine gliomas identifies three molecular subgroups and recurrent activating ACVRI mutations. Nat Genet 20I4, 46:45I-6.

92. Müller S, Almouzni G: A network of players in $\mathbf{H 3}$ histone variant deposition and maintenance at centromeres. Biochim Biophys Acta 2014, 1839:24I-50.

93. Baylin SB, Jones PA: A decade of exploring the cancer epigenome - biological and translational implications. Nat Rev Cancer 2011, II:726-34. 
94. Rius M, Lyko F: Epigenetic cancer therapy: rationales, targets and drugs. Oncogene 20I2, 3I:4257-65.

95. Rodríguez-Paredes M, Esteller M: Cancer epigenetics reaches mainstream oncology. Nat Med 2011, 17:330-9.

96. Best JD, Carey N: Epigenetic opportunities and challenges in cancer. Drug Discov Today 2010, I 5:65-70.

97. Wu G, Diaz AK, Paugh BS, Rankin SL, Ju B, Li Y, Zhu X, Qu C, Chen X, Zhang J, Easton J, Edmonson M, Ma X, Lu C, Nagahawatte P, Hedlund E, Rusch M, Pounds S, Lin T, Onar-Thomas A, Huether R, Kriwacki R, Parker M, Gupta P, Becksfort J, Wei L, Mulder HL, Boggs $\mathrm{K}$, Vadodaria B, Yergeau D, et al:: The genomic landscape of diffuse intrinsic pontine glioma and pediatric non-brainstem high-grade glioma. Nat Genet 2014, 46:444-50.

\section{FlOOOPrime}

\section{RECOMMENDED}

98. Lewis PW, Müller MM, Koletsky MS, Cordero F, Lin S, Banaszynski LA, Garcia BA, Muir TW, Becher OJ, Allis CD: Inhibition of PRC2 activity by a gain-of-function $\mathrm{H} 3$ mutation found in pediatric glioblastoma. Science 2013, 340:857-6I.

\section{FlOOOPrime}

99. Black JC, Manning AL, van Rechem C, Kim J, Ladd B, Cho J, Pineda CM, Murphy N, Daniels DL, Montagna C, Lewis PW, Glass K, Allis CD, Dyson NJ, Getz G, Whetstine JR: KDM4A lysine demethylase induces site-specific copy gain and rereplication of regions amplified in tumors. Cell 2013, I54:54I-55.

\section{FlOOOPrime

RECOMMENDED

100. Daigle SR, Olhava EJ, Therkelsen CA, Basavapathruni A, Jin L, BoriackSjodin PA, Allain CJ, Klaus CR, Raimondi A, Scott MP, Waters NJ, Chesworth R, Moyer MP, Copeland RA, Richon VM, Pollock RM: Potent inhibition of DOTIL as treatment of MLL-fusion leukemia. Blood 2013, 122:1017-25.

\section{FlOOOPrime RECOMMENDED}

101. Bantscheff M, Hopf C, Savitski MM, Dittmann A, Grandi P, Michon A, Schlegl J, Abraham Y, Becher I, Bergamini G, Boesche M, Delling M, Dümpelfeld B, Eberhard D, Huthmacher C, Mathieson T, Poeckel D, Reader V, Strunk K, Sweetman G, Kruse U, Neubauer G, Ramsden NG, Drewes G: Chemoproteomics profiling of HDAC inhibitors reveals selective targeting of HDAC complexes. Nat Biotechnol 20I I, 29:255-65.

\section{FIOOOPrime}

102. Filippakopoulos P, Qi J, Picaud S, Shen Y, Smith WB, Fedorov O, Morse EM, Keates T, Hickman TT, Felletar I, Philpott M, Munro S, McKeown MR, Wang Y, Christie AL, West N, Cameron MJ, Schwartz B, Heightman TD, La Thangue N, French CA, Wiest O, Kung AL, Knapp S, Bradner JE: Selective inhibition of BET bromodomains. Nature 2010, 468:1067-73.

\section{FlOOOPrime}

\section{RECOMMENDED}

103. Nicodeme E, Jeffrey KL, Schaefer U, Beinke S, Dewell S, Chung C, Chandwani R, Marazzi I, Wilson P, Coste H, White J, Kirilovsky J, Rice CM, Lora JM, Prinjha RK, Lee K, Tarakhovsky A: Suppression of inflammation by a synthetic histone mimic. Nature 2010, 468: $1119-23$.

\section{FlOOOPrime}

104. Singh MM, Manton CA, Bhat KP, Tsai W, Aldape K, Barton MC, Chandra J: Inhibition of LSDI sensitizes glioblastoma cells to histone deacetylase inhibitors. Neuro-oncology 201 I, I 3:894-903.

\section{FlOOOPrime} RECOMMENDED

105. Bar-Sela G, Jacobs KM, Gius D: Histone deacetylase inhibitor and demethylating agent chromatin compaction and the radiation response by cancer cells. Cancer J 2007, 13:65-9.

\section{FlOOOPrime}

RECOMMENDED

106. Sharma SV, Lee DY, Li B, Quinlan MP, Takahashi F, Maheswaran S, McDermott U, Azizian N, Zou L, Fischbach MA, Wong K, Brandstetter K, Wittner B, Ramaswamy S, Classon M, Settleman J: A chromatin-mediated reversible drug-tolerant state in cancer cell subpopulations. Cell 2010, 141:69-80.

\section{FIOOOPrime}

RECOMMENDED

107. Sobel RE, Cook RG, Perry CA, Annunziato AT, Allis CD: Conservation of deposition-related acetylation sites in newly synthesized histones H3 and H4. Proc Natl Acad Sci USA 1995, 92:|237-4|.

108. Xu M, Long C, Chen X, Huang C, Chen S, Zhu B: Partitioning of histone $\mathrm{H} 3-\mathrm{H} 4$ tetramers during DNA replication-dependent chromatin assembly. Science 2010, 328:94-8.

109. Allis CD, Berger SL, Cote J, Dent S, Jenuwien T, Kouzarides T, Pillus $L$, Reinberg D, Shi Y, Shiekhattar R, Shilatifard A, Workman J, Zhang Y: New nomenclature for chromatin-modifying enzymes. Cell 2007, 131:633-6. 